\title{
REVIEW PAPER ON STRUCTURAL BEHAVIOUR OF INDUSTRIAL PALLET RACK WITH BRACED AND UNBRACED FRAMES
}

\author{
Sourabh R. Dinde ${ }^{1}$, Rajashekhar S. Talikoti \\ ${ }^{l}$ PG Student, Late G. N. Sapkal College of Engineering,Nashik,Maharashtra, India \\ ${ }^{2}$ Head of Department, Late G. N. Sapkal College of Engineering, Nashik, Maharashtra, India
}

\begin{abstract}
According to the structural point of view Industrial Pallet rack structure can be considered typical steel framed structure. This work presents a general analysis of an industrial pallet rack structure, evaluating the influence of each of the components on the global stability. An analytical study for the sensitivity of pallet rack configuration in linear static equivalent lateral loads. The aim is to braced/unbraced frames were design and their analytical models are to be built in software. The finite element analysis is used to determine axial forces in beam and column, maximum storey displacement and buckling loads on braced/unbraced pallet rack structure. Bracing systems are mostly provided to enhance the stiffness factor of the structures with the seismic loads. Unbraced systems have mostly translational modes of failure and are very flexible due to excessive loads.
\end{abstract}

Keywords: Pallets Rack, Cold Formed Steel, Seismic Design, Finite Element Analysis, Buckling Capacity

\section{INTRODUCTION}

The scope of this thesis is the analysis of the earthquake response of a pallet storage rack made of thin-walled steel products. Storage racking systems made of thin-walled cold formed steel products are able to carry very high live load and can also raise considerable height. Thin walled cold formed elements are very efficient as far as strength and stiffness are concerned. Furthermore, they are very light. Usually their thickness ranges between 1-6 mm. The resistance to torsion of thin walled profiles is very small. The live loads of racks such as pallet loads often represent more; therefore the load presence and distribution on racking systems affect very much the response of these structures under seismic action.

The stability of a structure essentially means the stability of its equilibrium configuration or state. A structure loses it's stability due to various external as well as internal disturbances. In a cold-formed structure, instability becomes more prominent due to unsymmetrical and thin section. Stability analysis of an elastic structure mean by the buckling analysis. The main difficulties in cold-formed structural design are local, distortional buckling and warping of section in addition to this behaviour non-uniformity makes the structure more complex for analysis.

The seismic forces can in general be studied separately in the down-aisle direction and in the cross-aisle direction. The load condition for the relevant seismic design of the rack is the fully loaded rack, as the horizontal seismic action is maximized. The rack's structural systems withstanding the seismic actions in two directions 1. In the down-aisle direction: unbraced frames stability is provided by the beam-to-column connections.2. In the cross-aisle (the upright frames) direction: braced frames stability is provided by the Diagonal form bracing. These models have been analyzed in ETABs software.
Braced frame

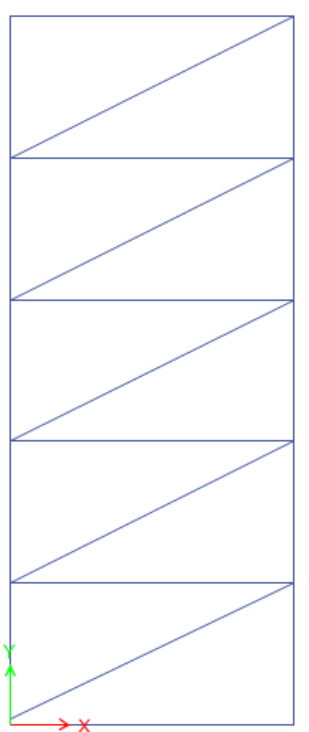

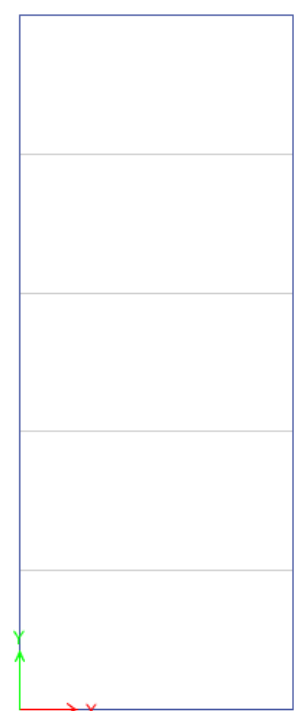

Unbraced frame

\section{LITERATURE REVIEW}

Experimental and analytical studies of the seismic performance of storage racks has been scarce and the results often are proprietary; and consequently, they have not significantly influenced the development of codes and regulations related to storage rack systems. This survey paper provides analytical investigations on the seismic response of storage racks are briefly reviewed. Gaps in knowledge requiring further research studies also are identified.

Murray J. Clarke et.al [1] has presented on the global buckling behaviour of high-rise steel storage rack frames. He studied that there is a problem in using the beam elements available in many commercial frame analysis 
programs which neglect torsional buckling and the coupling between axial, flexural and torsional deformation modes at the element level. It is shown that the mono-symmetric upright columns of a high-rise rack frame fail in a flexuraltorsional mode due to the shear-centre eccentricity of the sections, and that the 3D frame buckling analysis is more reliable in determining the critical members of a rack frame.

K.M. Bajoriaet.al [2] has presented that the most accurate method of seismic demand prediction on structures is nonlinear time history analysis. As an alternative to time history analysis, is the non linear static pushover analysis. The purpose of the push over analysis is to assess the structural performance by estimating the strength and deformation capacities comparing these capacities with the demands at the corresponding performance levels. Model was analyzed using non-linear static pushover analysis. Parameters selected for analysis and design are cross section of uprights, thickness of uprights, and stiffness of the connections. Base shear at the time of collapse is improved step by step either by changing the bracing combination or changing the cross section of upright at points where plastic hinges are forming initially.

Damien Koen [3] studied on the effect of discrete torsional provided by the frame bracing in the cross-aisle direction. The experimental testing of the column frames with Kbracing are been compared to finite elements prediction of displacements and maximum axial loads. Thus FEM is used to determine buckling loads on unbraced and braced column frames of various lengths.

James P. Planteset.al [4] has presented installation guidelines for industrial storage rack; and how a combination of improper installation, maintenance, and operational procedures led to a catastrophic failure of a warehouse storage rack system. The authors demonstrated that current installation guide lines do not provide for adequate stability of storage rack systems and propose that a change from guidelines to prescriptive requirements will provide a safer environment for building occupants and protect against costly property damage and business interruptions due to storage rack collapses.

N. Baldassinet.al [5] has studied the behaviour of base-plate connection of steel storage pallet racks under eccentric load is currently in progress. The testing rig and the test procedure have been presented. The level of the axial load applied to the upright, the behaviour of base-plate connection and the interaction between upright and baseplate element play a key role in joint response.

Gregory J. Hancock [6] has studied distortional mode of buckling for a rack structure with a cold form steel lipped channel columns including a additional flange stiffening lips which is known as rear flanges. These are used mainly for the bolting of braces to the channel section to the upright frames in rack storage system. analyzing the Theoretical and experimental models for buckling o columns and the result where check from a design chart which included calculation of torsional buckling stresses of various ranges of size of a channel section with rear flanges.
C.Kozkurtet.al [7] has studied structural storage of warehouses analyzed with finite element method. Each cell of rack system storages pallet which from $800 \mathrm{~kg}$ to $1000 \mathrm{~kg}$ weights and $0.80 \times 1.15 \times 1.50 \mathrm{~m}$ dimensions. Considering this load, total deformations and equivalent stresses of structural elements and principal stresses, tensile stresses and shear stresses of connection elements have been analyzed. Results were evaluated according to resistance limits of structural and connection elements.

N. Baldassinoet.al [8]design is usually performed adopting 2-D simplified models related to the main frame directions: i.e. down-aisle and cross-aisle direction. The frame stability in down-aisle direction, where usually bracing systems are missing, is ensured by the degree of continuity provided by joints. In the framework of a research work of pallet racks, are search on the response of base-plate joints under axial eccentric load is been under progress

\section{METHODOLOGY}

Over the years the evolution as far as the design and function of storage warehouses is concerned it have been determined by the lack of space, the high labor cost and the demands of modern production methods. The goods are no longer stored in one level only and they have to be easy to access and transfer from one place to other. Storage racking systems are the structures that answer exactly these needs. They are thin metallic structures used to store goods in height. Amongst their special characteristics is that they have to be standardized and adaptive. The design of their elements is an outcome of optimization as well as of the combination of experimental and computational methods, given the fact that every reduction of the total weight, every increase of the strength and every simplification of the installation procedure can significantly affect the economy of the whole structure.

Thus for storage purpose, the design of industrial pallet rack structure consideration with seismic loads have been analyzed. Study of structural behaviour difference between braced \& unbraced upright frames (column) in cross aisle.

\section{CONCLUSION}

Many of the studies have shown structural behaviour of connection of beam and column joints or installation of base plate for the analysis of pallet rack and much less research has been undertaken into more complex sections such as uprights for pallet racking. Over the last decade there has been an extensive amount of research into light gauge Zed sections. This paper has lead to many advances in coldformed steel design; however the design of complex sections such as perforated steel storage rack uprights still requires further research. Results on the structural behaviour on the analysis of industrial pallet rack with braced and unbraced frames have not been studied. In proposed work, the forces developed due to seismic action in $\mathrm{X}$ direction and $\mathrm{Y}$ direction, dead load and live load are considered and the results obtained from the above analysis are to be tabulated, compared and conclusions are drawn. 


\section{REFERENCES}

[1] [Gregory J. Hancock, Lip H. The, Murray J. Clarke,” Analysis and design of double-sided high-rise steel pallet rack frames", Faculty of Engineering and Information Sciences, Journal of Structural Engineering,(2004). 130 (7), 1011-1021.

[2] K.M. Bajoria and K.K. Sangle," Capacity Based Design of Cold Formed Storage Rack Structures Under Seismic Load For Rigid And Semi Rigid Connections", The 14the World Conference on Earthquake Engineering October 12-17, 2008, Beijing, China.

[3] Damien Koen," Structural Capacity of Light Gauge Steel Storage Rack Uprights", School of Civil Engineering, The University of Sydney, august2008.

[4] James P. Plantes, Deepak Ahuja, Ryan T. Chancey," A Case Study on the Collapse of Industrial Storage Racks", university of texas state, 2004

[5] N. Baldassino And R. Zandonini,"Performance of Base-Plate Connections of Steel Storage Pallet Racks", University of Trento, Italy 2000

[6] Gregory J. Hancock," Distortional Buckling of Steel Storage Rack Columns", Seventh International Specialty Conference on Cold-Formed Steel Structures, St. Louis, Missouri, U.S.A., November 13-14, 1984

[7] C. Kozkurt, A. Fenercioglu, M. Soyaslan,” Structural Analysis of Warehouse RackConstruction for Heavy Loads" World Academy of Science, Engineering and Technology Vol:6 2012-07-25

[8] N. Baldassino1 and R. Zandonini2,"Performance Of Base-Plate Connectionsof Steel Storage Pallet Racks" Assistant Professor, University of Trento, Trento, Italy

\section{BIOGRAPHIES}

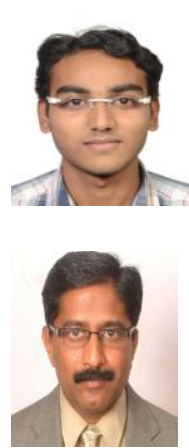

Sourabh Rajendra Dinde, PG Student, Late G. N. Sapkal College of Engineering Nashik,Maharashtra,India E-mail: sourabh.dinde@gmail.com

Dr. Rajashekhar S. Talikoti, Head of Department, Late G. N. Sapkal College of Engineering, Nashik, Maharashtra, India Email: rstalikoti@gmail.com 